\title{
Breast Cancer Cell
}

National Cancer Institute

\section{Source}

National Cancer Institute. Breast Cancer Cell. NCI Thesaurus. Code C12959.

Cells found in human breast cancers or extracted from cancers as established cell lines 